\title{
ЯЗЫКОЗНАНИЕ
}

\author{
А.С. Нилогов
}

\section{ОТ АНТИЯЗЫКОВОЙ МЕТОДОЛОГИИ К АНТИЯЗЫКОВОЙ ГЕНЕАЛОГИИ}

Аннотация. В статье на лингвогенеалогическом материале показано применение антиязыковой методологии. Объектом исследования является онтологический статус слова/антислова. Предметом исследования являются конкретные классы слов/антислов, такие как генетизмы и генеалогизмы, благодаря которым удаётся решить многие источниковедческие вопросы как классической документальной генеалогии, так и современной генетической генеалогии. Речь идёт о проблеме достоверного установления имён собственных тех наших предков, документальное подтверждение которых порой осложнено многими паралингвистическими факторами - например, плохой сохранностью первоисточников или их полным отсутствием. В статье используются такие методы, как генеалогчческий, герменевтический, исторический, источниковедческий, хронологический, этимологический, а также метод антиязыковой реконструкции. Исследование проиллюстрировано лингвистическими данными (антропонимами) из авторской родословной, насчитывающей более тысячи имён собственных предков и базирующейся на архивных первоисточниках из РГАДА, ГАПКа, ГАКО, ГАСО и отделов ЗАГС. Впервые в научный оборот вводятся такие классы слов/антислов, как генетизмы и генеалогизмы, а также их разновидности (подклассы слов/антислов).

Ключевые слова: лингвогенеалогия, онтологический статус слова, генетизмы, антиязыковая генеалогия, генеалогизмы, философия антиязыка, метрическая книга, ревизская сказка, писцовая книга, антропонимы.

Abstract. Based on the analysis of the lingvogeneological materials, the author of the article demonstrates how the antilanguage methodology can be applied. The object of the research is the ontological status of word/antiword. The subject of the research is particular classes of words/antiwords such as genetisms and genealogisms which allow to solve many historiographical issues both in classical documentary genealogy and modern genetic genealogy. The point at issue is the problem of authentic determination of personal names of those ancestors of ours whose names could be hardly read or even missed in primary sources. In his research Nilogov uses the methods of genealogical, hermeneutical, historical, historiographical, chronological and etymological analysis as well as the method of antilanguage reconstruction. The results of the research are illustrated by linguistic data (anthroponyms) from the author's geneaological tree which contains over thousand names based on primary sources such as the Russian State Archive of Ancient Acts, State Archive of the Perm Region, State Archive of the Kirov Region and Civil Status Registration Offices. For the first time in the academic literature the author introduces such classes of words/antiwords as genetisms and genealogisms and provides a description of their types (subclasses of words/antiwords). Key words: census record, church metric book, philosophy of antilanguage, genealogisms, antilanguage genealogy, genetisms, ontological status of word, lingvogenealogy, cadastre, anthroponyms

Дорог предок - дорого и его имя.

В.К. Харченко, Е.М. Черникова [1, с. 21]

Имя по сущности своей глубоко положительно, это сама положительность, само утверждение (назвать - утвердить на веки вечные, закрепить в бытии на всегда, ему присуща тенденция к нестираемости, несмываемости, оно хочет быть врезанным как можно глубже, в возможно более твёрдый и прочный материал и т.п.), в нём нет ни грана отрицания, уничтожения, оговорки (особая сторона имени - это «я» в чужих устах, я для другого в положительном аспекте). Поэтому вокруг имени сосредоточиваются всё положительные, утверждающие, хвалебно-прославляющие формы языковой жизни (оно глубоко эпично, с другой стороны, и эпос (также трагедия) не мо- гут быть анонимными, или псевдонимными, или неисторичными, то есть о заведомо вымышленном, типическом, только возможном лице, как роман). <...> Пока сохраняется имя (память), сохраняется (остаётся) в бытии именуемый, продолжает ещё жить в нём.

M.М. Бахтин [2, с. 146]

С точки зрения антиязыковой методологии [3], результаты генеалогических исследований представляют собой интересный лингвистический материал. Речь идёт о проблеме достоверного определения родственных связей, а именно: о корректном установлении имён собственных, документальное подтверждение которых часто осложнено плохой 
сохранностью первоисточников или их полным отсутствием. Поскольку антиязык работает с классами антислов, постольку для родословных изысканий также необходимо установить соответствующие классы антислов.

Введём понятие «онтологический статус слова», под которым будем понимать то, каким образом и в каком качестве существует слово в естественном живом человеческом языке. Другими словами, является ли слово - словом или антисловом? Способно ли слово полностью воязыковляться, а если только частично, то каковы пределы такового воязыковления? [4] Эти философские и одновременно лингвистические вопросы составляют содержание такой дескриптивной дисциплины, как философия антиязыка. Её объектом изучения является антиязык, состоящий из классов и подклассов антислов (предмет изучения). В философии антиязыка разрабатываются специальные методы усмотрения невоязыковляемых сущностей, а также наиболее эффективные способы именования вещей. Осталось дать определение антислову. Антислово - это такая антиязыковая единица, которая полностью или частично не может быть выражена в языке, то есть воплотиться как настоящее слово в совокупности всех его признаков. Поскольку имена людей (антропонимы, антропонимические единицы) также могут пребывать в статусе антислов, постольку необходимо выделить их в соответствующие классы и подклассы антислов с тем, чтобы уточнить собственно генеалогические приёмы дешифровки и реконструкции имён предков, чей онтологический статус нередко носит предположительный характер.

Начнём с такого примера, как наличие явных прямых предков, живущих в конкретном населённом пункте, в отношении которых невозможно определить точную родственную связь. Это связано с несохранившимися документами, удостоверяющими такую связь, как-то: наличие записей о бракосочетании, в которых указаны девичьи фамилии прямых предков по женским линиям (например, метрические записи и ревизские сказки периода 3-5 ревизий 1762, 1782, 1795 гг.). Вероятно, что документально искомые предки зафиксированы в различных первоисточниках, но из-за описанной проблемы они не могут быть в точности названы прямыми предками, оставаясь таковыми фактически. Их имена собственные составляют один из классов антислов, который назовём генеалогизмами (другой вариант - антропонимологизмы). Уточним, что речь идёт о документально зафиксированных людях и их именах (в полном варианте ФИО), но связь с которыми затруднительна в силу нехватки прямых или косвенных документальных доказательств. По сути, имена ваших прямых предков сохранились в документах, но вы не можете подтвердить принадлежность к ним. Причём среди таких генеалогизмов могут быть разного типа антислова: например, полные генеалогизмы, включающие фамилию, имя и отчество вашего предка (Иван Петров/Петрович Смирнов), неполные (частичные) генеалогизмы, включающие или имя и фамилию (Иван Смирнов), или имя и отчество (Иван Петрович), или отчество и фамилию (Петров/ Петрович Смирнов), или фамилию (Смирнова), или отчество (Петров/Петрович), или имя (Иван).

Теперь приведём конкретные примеры, воспользовавшись огромным источниковедческим материалом из нашей собственной родословной. Проиллюстрируем класс генеалогизмов следующими примерами. Начнём с полных генеалогизмов, состоящих из имени, отчества и фамилии наших далёких предков. Так, в числе наших прямых предков по отцовской линии в 1-й половине XIX в. встречается фамилия «Кузнецов» (деревня Нижняя Коса Чердынского уезда Пермской губернии). 15(27).1.1843 наш прапрапрапрадед Изосим Моисеев Нилогов женился на Ирине Ивановой Кузнецовой [5, л. 76об.77, 91об.-92]. Отцом И.И. Кузнецовой был Иван Фёдоров Кузнецов, чьё происхождение и выводит нас на обозначенную проблему. Дело в том, что согласно данным третьей ревизской сказки по Нижней Косе за 1762 г. в деревне проживало несколько семей Кузнецовых, ведущих своё происхождение от одного предка. В семье Ивана Макарова Кузнецова числился 15-летний сын Фёдор Иванов Кузнецов и в семье Ивана Дмитриева Кузнецова также числился 15-летний сын Фёдор Иванов Кузнецов (дилемма полных тёзок). Оба Фёдора Кузнецова были женаты, но ни у кого из них ещё не родился сын Иван, который впоследствии бы стал связующим коленом между И.И. Кузнецовой и И.М. Нилоговым. Четвёртая (1782), пятая (1795), шестая (1811) и седьмая (1816) ревизские сказки по Нижней Косе не сохранились или ещё не выявлены (хотя, скорее всего, всё-таки не сохранились). Однако до нас дошли метрические книги по Косинской Николаевской церкви за 1760-1779 [6] и 1800-1829 гг. (и далее с некоторыми лакунами) [7], в которых за 18(29).4.1767 была найдена информация о крещении у крестьянина Нижней Косы Фёдора Кузнецова - сына Ивана [8, л. 188об.]. Но поскольку в метрической записи того периода не указывалась мать новорождённого, а у отца нередко опускалось и отчество, да и сведения о восприемниках, то есть крёстных, были введены в метрики чуть позже, постольку сейчас невозможно однозначно установить, у какого конкретно Фёдора Иванова сына Кузнецова родился сын Иван. По восьмой ревизии 1834 г. по Нижней Косе Ивану 
Фёдору Кузнецову - 60 лет, то есть он родился в около 1774 г. [9, л. 157об.]. Так как возраст людей в метриках и ревизиях не всегда фиксировался точно (если не сказать больше), остаётся допустить, что Иван Фёдоров Кузнецов мог родиться в 1767 г., ведь в метрике за 1774 г. и за 1770-е гг. нами не найдена запись о рождении ещё одного Ивана [6]. Конечно, искомый нами Иван мог родиться и в 1780 г. (или в начале 1780-х гг.), однако метрические книги за эти годы отсутствуют в Государственном архиве Пермского края. Таким образом, проблема точного документального отождествления Ивана Фёдорова Кузнецова с семьёй его отца остаётся в подвешенном состоянии. Пока не будут выявлены дополнитель- ные архивные свидетельства такой родственной связи, линия Кузнецовых на нашем родословном древе будет пребывать в антиязыковом статусе. Другими словами, наше родство с ветвью Кузнецовых однозначно подтверждается документальными источниками вплоть до 2-й половины XVII в., но проблематизируется на период третьей ревизии 1762 г. [10, л. 795-796], когда одновременно зафиксированы две ветви рода Кузнецовых, каждая из которых может являться нашей прямой родственной линией, если вести отсчёт от Ирины Ивановой Кузнецовой.

Для наглядности приведём фрагмент схемы нашего родословного древа для линии Кузнецовых:

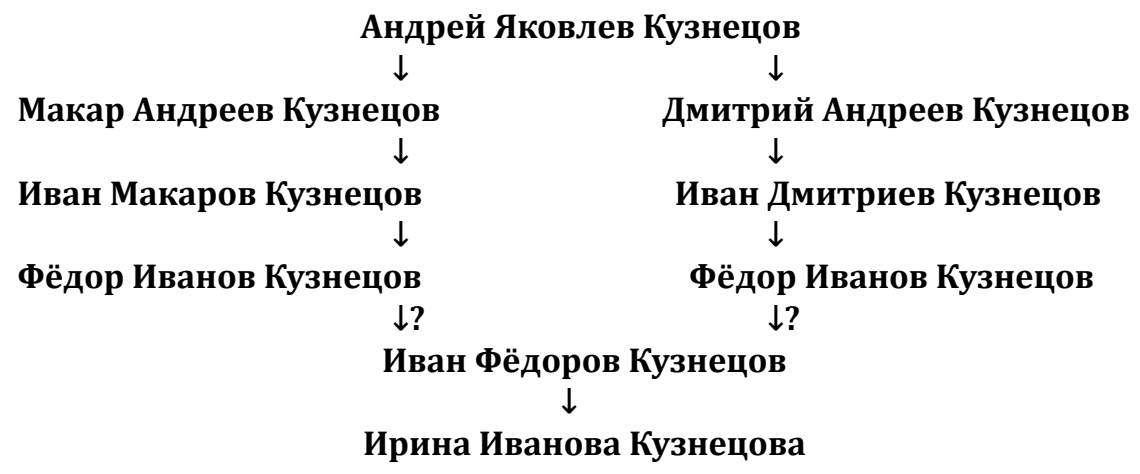

Следовательно, имена собственные представителей рода Кузнецовых, начиная от колена Фёдоров Ивановых (по двум смежным родственным линиям) и заканчивая коленом Макара и Дмитрия Андреевых с точки зрения нашей антиязыковой методологии будут являться антисловами, а именно - генеалогизмами. Причём необходимо уточнить, что здесь речь идёт о разных типах генеалогизмов - полных и неполных. Поскольку документально подтверждается, что отцом Ивана Фёдорова Кузнецова мог быть и один Фёдор Иванов Кузнецов, и второй Фёдор Иванов Кузнецов, то в нашем случае мы имеем дело с полным генеалогизмом, существующим в двух ипостасях (при условии, если мы перейдём на биографический уровень этих людей - носителей своих полных имён собственных). Антропонимически и документально понятно, что точное имя собственное отца Ивана Фёдора Кузнецова - Фёдор Иванов Кузнецов. Правда, на уровне дополнительной метрической информации проблема осложняется наличием двух претендентов - полных тёзок.

Таким образом, исходя из предложенной нами антисловной номинации для подобных генеало- гических случаев, необходимо констатировать следующее: в приведённой родословной схеме в статусе антислов-генеалогизмов приведены, вопервых, полные генеалогизмы «Фёдор Иванов Кузнецов» и «Фёдор Иванов Кузнецов», благодаря которым мы можем реконструировать точное полное имя собственное без привязки к метрической информации - Фёдор Иванов Кузнецов (ведь нами документально точно установлено, что отцом Ивана Фёдорова Кузнецова мог быть именно Фёдор Иванов Кузнецов, так как других претендентов в ревизии не зафиксировано; во-вторых, полные генеалогизмы «Иван Макаров Кузнецов» и «Иван Дмитриев Кузнецов», благодаря которым мы можем реконструировать точное неполное имя собственное без привязки к метрической информации - Иван Кузнецов; в-третьих, полные генеалогизмы «Макар Андреев Кузнецов» и «Дмитрий Андреев Кузнецов», благодаря которым мы можем реконструировать точное неполное имя собственное без привязки к метрической информации - Андреев Кузнецов.

И теперь наша родословная схема будет выглядеть таким образом:

Андрей Яковлев Кузнецов (полный антропоним)

(есть отождествление с конкретным человеком) 


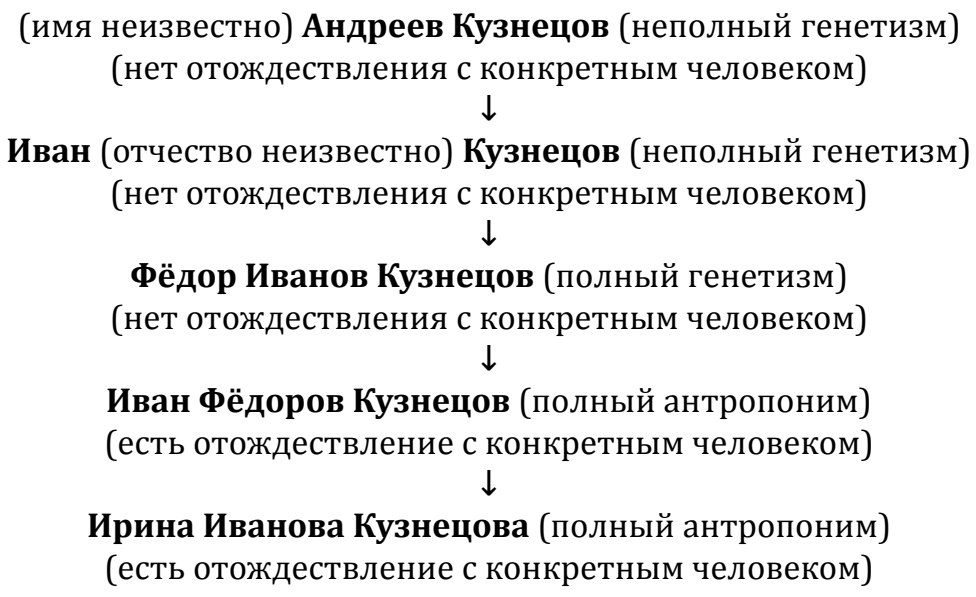

Обратите внимание, что в данной схеме представлены разные имена собственные - как конкретных людей, метрически подтверждённых, так и реконструированные реально живших людей. Чтобы исключить путаницу в терминологии, мы предлагаем ввести термин «генетизмы» для обозначения таких реконструированных форм имён собственных (как полных, так и неполных), которые с точки зрения антиязыковой методологии так же, как и генеалогизмы, являются антисловами. Несмотря на тот факт, что нами точно реконструирован такой антропоним, он всё равно остаётся генетизмом, не будучи отождествлённым с конкретным человеком - предком из родословного дерева. Конечно, если мы имеем дело с единственно возможной идентификацией конкретного человека с тем или иным именем собственным, то в таком случае, наверное, можно говорить о полном/неполном антропониме, но в силу неустранимой гипотетичности такой идентификации нам представляется уместным использовать именно антиязыковую терминологию, так как онтологический статус подобных «антропонимов» носит не подлинно словесный, а антисловесный характер. (С другой стороны, можно допустить и такую ономастическую номенклатуру: реальный антропоним (имя собственное реального идентифицированного человека; в нашей общей терминологии антиязыка (ОТЯ) - отсутствует (если не углубляться в принцип «изначального опоздания»), а в специальной терминологии антиязыка (СТЯ) - ДНК-генеалогизм), реконструированный антропоним (имя собственное реального частично идентифицированного человека; в нашей терминологии - генетизм) и гипотетический антропоним (имя собственное реального неидентифицированного человека; в нашей терминологии - генеалогизм).)

В заключение вновь приведём исходный вариант родословной схемы по линии Кузнецовых, чтобы доказать то, каким образом можно расширить методологию построения генеалогических древ с точки зрения антиязыка. Данная схема вполне правомочна с позиции классической генеалогии, но более аргументативна с позиции антиязыковой генеалогии.

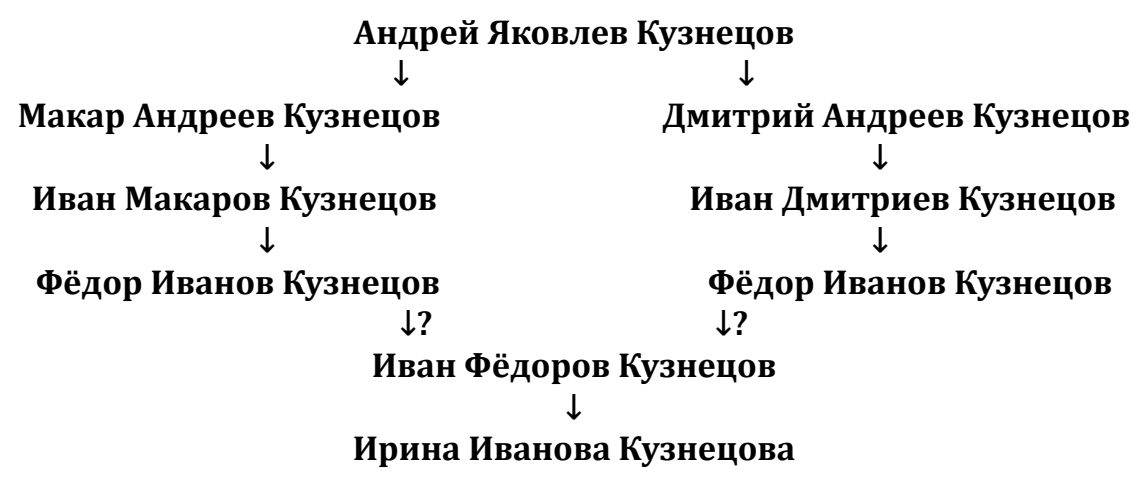

До тех пор пока не будет документально установлена прямая ветка предков по линии Кузнецовых, приведённые сведения будут носить антиязыковой статус. Правда, такое положение дел, связанное с пробелами в архивных источниках, может оказаться окончательным, а потому приёмы антиязыковой методологии в любом случае расширяют возможности классической генеалогии за счёт ранее отбраковываемого материала. 
Особый тип генеалогизмов представляют «вообще безымянные» имена собственные, которые принадлежат жёнам наших прямых предков, чьи имена собственные неполные - или имя, или отчество, или реконструированное прозвище без имени, или имя и отчество с документально отмеченным прозвищем, которое ещё не превратилось в фамилию (безымянная жена такого предка не может быть атрибутирована по прозвищу мужа, но безымянная жена их сына может быть атрибутирована по фамилии сына, которая у его отца была ещё прозвищем). В использованных примерах мы ни разу не упомянули о других неполных (частичных) генеалогизмах и генетизмах. Обратимся к женским генеалогическим линиям, информация о которых и так зачастую неполна, но в нашем случае она может быть увеличена посредством антисловного именования. Нам осталось разобрать такие неполные генеалогизмы, которые состоят только из имени и отчества, только из имени, только из отчества и только из фамилии. Если дополнить нашу родословную схему именами собственными жён, то мы как раз и обнаружим искомые неполные генеалогизмы.

Наша дополненная схема с учётом женских линий будет выглядеть так:

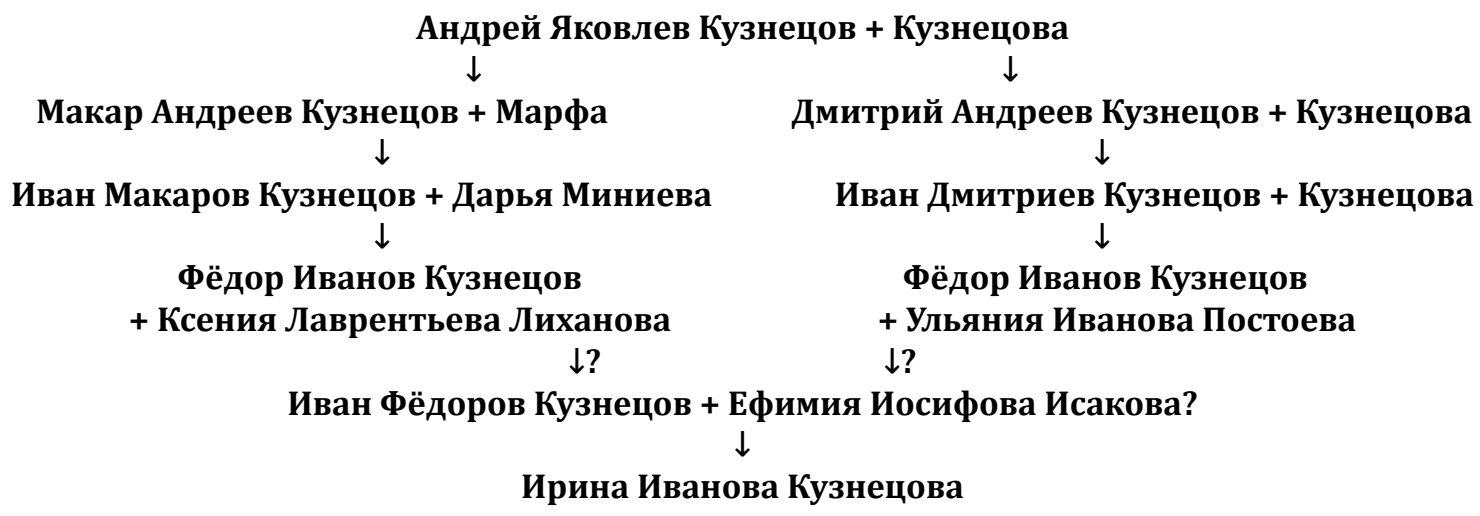

В данной схеме мы имеем дело как с неполными антропонимами, так и с неполными генеалогизмами и генетизмами. Начнём с Андрея Яковлева Кузнецова. Имя собственное его жены нам неизвестно, зато очевидно, что её фамилия в замужестве - Кузнецова. Такой способ номинации нами повсеместно используется в собственном родословии, позволяя хотя бы косвенно поименовать реально существовавшего предка. Далее на уровне детей А.Я. Кузнецова мы сталкиваемся с двумя параллельными линиями наших потенциальных предков: имя Марфа является неполным генеалогизмом, а фамилия Кузнецова - неполным как антропонимом, так и неполным генеалогизмом (неполным генетизмом это имя собственное, на наш взгляд, может и не быть, потому что мы, именуя косвенным способом, не дублируем фамилию по мужу для жены, чьё настоящее имя известно, тогда как дополнительные номинации, не связанные с прямыми отношениями «предок - потомок» (например, фамилии по другим мужьям) для нас избыточны). На уровне жены Ивана Макарова Кузнецова - Дарьи Миниевы - получаем неполный генеалогизм, включающий только имя и отчество. На уровне жён Ф.И. Кузнецовых перед нами исключительно полные генеалогизмы (а также неполный генетизм «Кузнецова» для мужней фамилии по обоим Кузнецовым). Наконец, на уровне второй жены Ивана Фёдорова Кузнецова воз- никает определённая трудность, связанная с установлением точной девичьей фамилии для Ефимии Иосифовой (по первому замужеству - Снигиревой). В результате анализа метрических книг удалось предположительно установить её девичью фамилию - Исакова. Таким образом, мы встретили следующие неполные генеалогизмы: только из имени и отчества («Дарья Миниева»), только из имени («Марфа»), только из фамилии («Исакова»), а также неполный генетизм, состоящий только из фамилии «Кузнецова».

Что касается неполных (частичных) генетизмов, то нам ещё предстоит найти примеры, состоящие только из имени и отчества и только из имени. Возможно, на этот статус могут претендовать такие имена собственные из нашей родословной, как «Васюк Остафьев», доводящийся нам прямым мужским предком по линии Нилоговых в 15-м поколении. Фамилия «Нылогов» [11] впервые зафиксирована в нашем роду в переписной книге Чердынского уезда 1678 г. (деревня Нижняя Коса) [12, л. 615]. До 1678 г. имеется ещё три первоисточника по Нижней Косе, в которых встречаются наши предки, правда, уже без фамилии (впервые фамилия в форме «Нылыгов» зафиксирована ещё в 1623/1624 гг. [13, л. 113об.; 14, л. 49об.]). Это документы за 1647 [15], $1623 / 1624$ [13; 14] и 1578/1579 гг. [16; 17; 18]. Во всех трёх источниках мы фиксируем наших пред- 
ков с помощью сопоставления и сравнения имён собственных всех жителей данного населённого пункта, выявляя потенциальных кандидатов на место наших прямых предков. Так, например, в 1678 г. записан целый куст родственников с фамилией «Нылогов»: семья Пронки Федосеева сына Нылогова, семья Евсийки Федосеева сына Нылогова, семья Конанки Семёнова сына Нылогова (живёт в старом дворе, что был двор Петрушки Семёнова) и семья Архипки Никитина сына Нылогова. Наша прямая линия идёт от Архипки Никитина сына Нылогова [12, л. 614об.-615]. В 1647 г. находим в Нижней Косе семью Федоски Меркурьева с сыном Евсевейком, а также семьи Конанки Семёнова с племянником Афонкой Баженовым и Кондрашки Василева с сыном Якушкой; пустой двор умершего Петрушки Семёнова [15, л. 231-232об.]. В 1623/1624 гг. встречаем несколько жителей Нижней Косы с отчеством «Васильев»: Микитка Васильев, Меркушка Васильев с сыном Федосейкой, Кондрашка Васильев, Сенка Васильев с сыном Петрушкой [13, л. 131об.; 14, л. 55]. Наконец, в 1578/1579 гг. обнаруживаем Тренку да Васюка Остафьевых [16, л. 38-38об.; 17, л. 20об.; 18, с. 34]. Путём несложных допущений (через установление прямого и косвенного родства) делаем вывод о том, что все эти крестьяне с отчеством «Васильев» являются родными братьями, что подтверждается затем записью за 1678 г., где все они значатся под одной фамилией «Нылогов». Таким образом, можно предположить, что единственным претендентом на отождествление их общего отца - Василия - является именно Васюк Остафьев, чьё имя собственное можно расценивать как неполный генетизм, состоящий из собственно имени и отчества.

Пример неполного генетизма в виде только одного имени в имени собственном можно рассмотреть на материале того же Чердынского уезда конца XVI - начала XVII вв. Не конкретизируя прослеживание цепочки по линии такого рода, как «Кыласовы», отметим, что нам удалось установить, что ещё в 1608 г. в деревне Копрос (Купрост) на Иньве проживал Степан Иванов сын Килосов [19, л. 21]. В 1578/1579 гг. в Копросе находим Ивашку Никитина [16, л. 40об.; 17, л. 21об.; 18, с. 37], которого отождествляем с отцом Степана сына Килосова. Да, Ивашку мы можем реконструировать вполне конкретно, но посредством такого отождествления получаем ещё одного представителя из рода Кыласовых - Никиту, чьё имя собственное может быть определено как неполный генетизм, состоящий только из имени.

Конечно, приведённые примеры свидетельствуют о том, что содержащаяся в них информация не может быть существенным образом уточнена, потому что никаких других документов от эпохи XVI-XVII вв. до нас не дошло. Это так. Но для более позднего времени возможны находки дополнительных источников, которые позволят перевести найденные имена собственные наших предков из антисловного статуса в словесный статус (с теми или иными допущениями).

Обмолвившись о существовании «ДНКгенеалогизмов», дадим соответствующую трактовку этим антисловам. «ДНК-генеалогизмы» - это все имена собственные в классической родословной, генетически не удостоверенные как прямые предки или потомки. Речь может идти не только о женской измене, когда согласно современным статистическим данным около 10\%-15\% всех детей в семьях воспитываются не своими биологическими родителями. Ситуация намного сложнее: никакая документальная родословная не может гарантировать полного соответствия между референтом (реальным предком или потомком) и языковым знаком (именем собственным). После того как появился новый метод генетической генеалогии, или ДНК-генеалогии, встал фундаментальный вопрос о достоверности даже тех метрических данных, которые с точки зрения классической документальной генеалогии не вызывали серьёзных опасений. Да, сомнения в истинности устных родословий всегда существовали (но, как ни странно, некоторые устные предания, например, казахские шежире, генетически подтверждаются [20]), да и относительно документальных генеалогий сохранялось определённое подозрение, однако, тем не менее, современная традиционная генеалогия нуждается в критике собственной методологии и необходимом расширении её посредством антиязыковой и генетической генеалогий.

Если посмотреть на данную проблему ещё и с точки зрения всего человеческого генома, то окажется, что в нашем хромосомном наборе будет отсутствовать генетический материал многих наших биологических предков. Дело в том, что в процессе мейоза (деления клетки) происходит так называемый кроссинговер (пересечение, перекрёст), то есть обмен участками гомологичных (парных) хромосом, в результате чего количество возможных сочетаний увеличивается в разы, что и обеспечивает такое разнообразие людей. Однако со временем перетасовка в геноме приводит к такому состоянию, при котором теряется предковый генетический материал, размываясь тем сильнее, чем глубже в историю. В этой связи встаёт вопрос об антиязыковом статусе имён собственных (как антислов) тех предков, чей генетический материал отсутствует в их потомках, несмотря на то, что они являются прямыми предками с известными именами собственными («ДНК- 
генетизмы»). Данный генетический парадокс может коррелировать с законом редукции предков, претендуя на самостоятельное бытование в виде закона редукции ещё и генетических предков: даже при реальном существовании далёких предков их количество уменьшается в геноме, расходясь как с конечным числом предков, так и с гипотетическим числом редуцированных близкородственных предков. Речь идёт об обратной пропорциональной зависимости уменьшения генетического материала от далёких предков на геометрическую прогрессию возрастания числа самих предков в прошлом (с поправкой на закон самородственности). Если от родителей мы получаем по 50\% от их генома, то уже от бабушек и дедушек - только по 25\% их генома, причём эти показатели не являются строго пропорциональными, а получаются случайным образом. Тем не менее, тенденция по сокращению генетического материала от дальних предков очевидна, даже несмотря на наличие у них близкородственных браков, которые не полностью могут компенсировать размывание генетического материала.

Антиязыковая методология призвана помочь восполнить додокументальные и документальные пробелы, разбирая имена собственные с позиции их онтологического статуса. Статус каждого имени собственного в родословной должен быть определён с точки зрения его словности/антисловности. Этим как раз и достигается определённая точность в именовании, столько востребованная в гуманитарных и общественных науках. Возьмём такой простой пример: не всегда удаётся точно установить имя собственное матери вашего прямого предка. Поскольку женский пол часто не фиксировался в документах, постольку возникают большие сложности в идентификации женского имени собственного с реальной женщиной. Даже при наличии самой церковной записи о бракосочетании спорадически удаётся определить имя матери, ведь нередки повторные браки, когда в семье воспитываются дети от разных матерей (при второженитьбе), а при второзамужестве от разных отцов (родственных нюансов может быть очень много). Бывают случаи, когда лакуны в документах сопровождаются описками/ошибками и прямым искажением фактических сведений, записываемых со слов сказывающих (отсюда - сказки, в том числе ревизские).

Продемонстрируем вышесказанное таким примером: в числе наших прямых предков по линии Арчуговых в XVIII в. значится Агафия Данилова, причём первое женское имя собственное, встречающееся у Арчуговых, от которых идёт наша родственная ветвь. В метрической книге о смерти по Стато-Троицкой церкви села Старый Посад за 1756 г. мы находим запись от 22 декабря по старо- му стилю о погребении жены крестьянина Сухой речки Кондратья Арчегова - Агафьи Даниловой дочери (без указания возраста) [21, л. 1008об.]. Это самая ранняя метрическая книга по данной церкви. Следовательно, в ревизской сказке по Сухой речке за 1763 г. информации об умершей до ревизии жене Кондратия (он же - Конон/Конан) Арчугова нет [22, л. 55об.]. Сын Конана Семёнова Арчугова - Филипп - родился в около 1713 г. [23, л. 262об.], однако является ли Агафья Данилова его биологической матерью достоверно сказать невозможно, так как отсутствует документальная запись об этом (скорее всего, является), а ведь у К.С. Арчугова могла быть не одна жена (кто знает: возможно, Агафья Данилова была его второй женой, а Филипп мог родиться от первой жены, умершей сразу после родов или чуть позже и нигде документально не зафиксированной). Таким образом, имя собственное «Агафья Данилова» в числе наших прямых предков будет обладать антисловным статусом, являясь неполным генеалогизмом (и даже квазигенеалогизмом, т.е. вследствие своей негативности - псевдогенеалогизмом). А сколько таких примеров можно найти в родословиях других людей! Да даже на собственном генеалогическом дереве их найдётся несколько десятков, ставя под большой знак вопроса методы классической документальной генеалогии. Антиязыковая методология предполагает осуществление полномасштабной ревизии для любой реконструированной документальной родословной, независимо от аристократического или неаристократического происхождения предков. Конечно, можно нафантазировать себе огромное количество имён далёких предков или связать свой крестьянский род с графским родом, но и в этих экстравагантных случаях мы будем иметь дело с антиязыковыми методами и приёмами по удостоверению имён собственных в качестве антислов.

Чего только стоит история с ДНК-тестированием потомков Рюрика - Рюриковичей из древних российских дворянских родов по прямой мужской линии на Y-хромосому. В результате проведённого исследования было определено, что одни Рюриковичи являются носителями гаплогруппы R1a1 (Оболенские, Волконские, Барятинские и др.), другие - гаплогруппы N1c1d (Гагарины, Кропоткины, Путятины, Хилковы и др.), третьи - вообще гаплогруппы I2a2 (Святополк-Четвертинские), однако в целом ситуация оказалась настолько запутанной, что требуется масштабная ДНК-экспертиза древней ДНК из исторических захоронений самых ранних из возможных Рюриковичей (ср.: [24], [25]). Причина такого несовпадения - женская измена, в результате которой один ребёнок был рождён от прямого генетического потомка Рюрика, а другой - 
от того мужчины, с кем законная жена этого потомка Рюрика изменила. Номинально же все рождённые дети получили юридический статус Рюриковичей, несмотря на то, что только некоторые из них имели на это полное право, будучи прямыми биологическими потомками.

Также стоит отметить и такие генеалогизмы, которые относятся к гипотетическому установлению родства в случае частичного отсутствия имён предков, не сохранившихся в период документальной фиксации - например, для XVII в. (писцовая книга). Если ваши корни прослежены до начала XVIII в., то есть смысл проследить их чуть глубже - во вторую половину XVII в., учитывая тот факт, что у ваших потенциальных предков, живших в то время, уже имелись и имена, и отчества, а главное - фамилии. Допустим, что вам удалось установить вашего дальнего предка Ивана (имя) Варфоломеева (фамилия), жившего в начале XVIII в. Естественно, что ваша документально удостоверенная родословная не может быть ограничена только началом XVIII в., ведь и в XVII в. жили предки Ивана Варфоломеева. Можно зафиксировать предка в форме отчества (для прозрачных фамилий, образованных от имён, отчеств, дедичеств [притяжательная форма от имени деда, употреблявшаяся вместе с отчеством или вместо него. - Прим. А.Н.] и прадедичеств (?)) «Варфоломеев сын» и в форме имени «Варфоломей». Ср.: В.Б. Кобрин: «Известно, что большинство русских фамилий развилось из отчества и носит патронимический характер. Патронимичны и наиболее распространённые фамильные форманты -ов, -ее, -ин, и более редкие -овых, -евых, -иных, -ых, -аго, -ово. Лишь формант -ский (-ской, -цкий, -цкой) скорее топоминичен. Господство патронимии в фамилиях приводит к тому, что отделить фамилию от отчества или “дедичества" трудно. Говорить о фамилии можно лишь тогда, когда ею пользуются потомки лица, носившего имя, ставшее основой фамилии, в третьем поколении. <...> Однако отделить фамилию от отчества и тем более от дедичества далеко не всегда так легко: для этого необходимо знать генеалогию изучаемого лица, знать, пользовались ли этим прозванием его потомки. Для каждого же конкретного лица функции дедичества или отчества (без -вич) приближались к функциям фамилии: были дополнительным различительным элементом и указывали на родственные связи. Поэтому правомерно объединение их с фамилией условным термином “родовое прозвание” " [26, с. 180, 181, 223-224].

Зная особенности образования фамилий на той или иной территории, можно с определённой уверенностью полагаться на приведённые антропонимические приёмы. Правда, онтолого-лингвистиче- ский статус данных реконструированных именных форм, документально нигде не отмеченных, тем не менее, возможен как антисловный (гипотетические генеалогизмы как подкласс антислов). А бывают примеры того, что невозможно однозначно установить - отчество перед нами или сокращённый вариант имени собственного, состоящего из имени и фамилии (частое явление в ранних межевых и писцовых книгах XV-XVII вв.).

Например, в нашем родословном древе имеется несколько десятков подобных казусов, в частности, связанных с фамилией «Варфоломеев». В числе наших предков с такой фамилией - Иван Семёнов Варфоломеев, родившийся в 1840-е гг. Глубже проследить линию Варфоломеевых пока не удалось, но очевидно, что в числе предков Семёна Варфоломеева по прямой мужской линии были люди, для которых мы можем установить неполное имя собственное в виде неполного генеалогизма для отчества («Варфоломеев (сын)») и имени («Варфоломей»), а также, вероятно, и для собственно фамилии «Варфоломеев», которую носили все прямые предки Семёна Варфоломеева до предка, у которого можно гипотетически постулировать только отчество «Варфоломеев», но ещё не фамилию. А поскольку невозможно точно установить количество таких носителей фамилии «Варфоломеев», то мы считаем данное именование избыточным.

Приведём второй случай, связанный с бытованием такой фамилии, как «Григорьев». Первым документально зафиксированным представителем этой фамилии был наш прямой предок Пётр Григорьев из Ильинского острожка Кунгурского уезда, родившийся во 2-й половине XVII в. Нетрудно предположить, что даже если он был первым носителем этой фамилии, то у его отца было отчество «Григорьев (сын)», а у деда - имя «Григорий». Данные имена собственные в нашей терминологии являются антисловами - неполными генеалогизмами.

Другой пример касается гипотетического определения родства, относящегося к додокументальному периоду, когда в той или иной местности вообще не велось никакого сбора информации о проживающем населении, а потому аналогичная предыдущей реконструкция имён наших предков будет менее точна относительно поколенной росписи. Вот интересный случай: на начало XVII в. мы имеем документально зафиксированного или документально восстановленного предка «Ивана Котегова». Вероятно, впервые фамилия «Котегов» упоминается в 1614/1615 гг. в дозорных книгах Вятской земли, а точнее: в Сырьянском стане Слободского уезда (починок, что был Новокрещёна Игнашки Ожмегова: Никонко Котегов, Тихонко Котегов, Офонка Котегов [27, л. 516], а также на землях татар, чувашей 
и отяков в Каринском стане (погост Омсин - Токташ Котегов [28, л. 515об.], Гришка Котегов [28, л. 516], погост Новой - Елгозя Котегов [28, л. 517], деревня на реке на Чепце против устья речки Лекмы - Гришка Котегов [28, л. 525], деревня на реке на Чепце на Кушмане на старом городище - Тулешко Котегов [28, л. 525об.]).

Считается, что фамилия образована от комипермяцкого или удмуртского имени «Котег» («Котэг», «Катег»), в переводе обозначающего «трудолюбивый». Такую версию разделяет автор-составитель «Словаря пермских фамилий» Е.Н. Полякова («КОТЕГОВ. Житель Сухореченской сотни Крысанф Гаврилов сын Котегов, 1782. Кун1, 320. Фамилия от прозвища Котег из коми-пермяцкого дохристианского имени Котег, возможно, 'трудолюбивый'» [29, c. 190]), ссылаясь на филолога С.А. КривощёковуГантман («Котегов, от Катег, что С.К. Бушмакин этимологизирует как «трудолюбивый» [30, с. 92], «КОТЕГОВ, от Kameг. С.К. Бушмакин удмуртское катег этимологизирует как “трудолюбивый”» [31, с. 83]), которая в свою очередь принимает точку зрения краеведа С.К. Бушмакина: «Антропонимы удмуртского происхождения в основном состоят из однокоренных имён существительных и прилагательных, оформленных специфическими суффиксами, в настоящее время в большинстве своём являющимися уже непродуктивными. Особенно широко распространёнными суффиксами, с помощью которых образованы личные имена, являются следующие: -эг (-ег): Ож(м)ег, Ожег, Удэг, Урсэг, Идэг, Гозэг, Котэг, Пелег, Сырчег, Кузег, Кулэг, Шудэг, Ужег, Чужек (Ӵужек), Юрег, Мушег, Зумег (диал. Ӟумег), Кунэг, Тылэг, Керӟег, Кеӟег, Аслэг, Кынэг, Пислэг, Кылег, Ненег, Кудэг, Кычек, Козэг, Кызнэг, Кусэг, Лунэг, Лислэг и т.д.» [32, с. 263-264] (ср. также: «Котэг “сырой, мокрый, мочащийся"» [32, с. 267]).

Интересен тот факт, что фамилия «Котегов» встречается как у русских, так и нерусских (в основном у вотяков, то есть удмуртов) жителей Вятской земли. В документах первой половины XVII в. отмечены как отчества в форме «Котегов», так и фамилии «Котегов» (в форме «сын Котегов»), причём вместе с нерусским именем и отчеством «Котегов» записаны русские фамилии. Это свидетельствует о постепенной русификации местного населения по мере включения его в налоговый документооборот. Очевидно, что первое упоминание формы «Котегов», зафиксированное в 1614/1615 гг., может быть отмечено именно в статусе фамилии, хотя процесс «фамилизации» также шёл по мере включения коренного населения в учётный документооборот. Не совсем прояснён вопрос о том, могли ли носить фамилию «Котегов» русские, потому что трудно установить по форме «Гришка Котегов», кто конкретно имеется в виду - то ли русский, то ли русифицированный вотяк. Ответ на этот вопрос может дать только ДНК-генеалогия, которая может по Y-хромосоме мужских носителей фамилии установить гаплогруппу родоначальника фамилии и, предположительно, этнический состав.

Столь неоднозначная этимология фамилии «Котегов» влечёт за собой проблему подсчёта поколений. Если вести отсчёт от Ивана Котегова, который жил во 2-й половине XVI в., вероятно, на Вятской земле и который доводится мне прямым предком в 17 колене, то логика образования фамилии подсказывает ещё пару прямых предков. Имеется в виду то обстоятельство, что фамилия «Котегов» у Ивана Иванова сына Котегова досталась ему от отца - Ивана Котегова, который, следовательно, получил фамилию уже от своего отца, имя и отчество которого неизвестны. Но можно предположить, что форма «Иван Котегов» содержит имя и фамилию, которая должна была образоваться от отчества «Котегов», и в результате мы имеем ещё одного предка в 18 колене без имени, но с отчеством «Котегов», время жизни которого можно отнести к XVI в. В генеалогии нередки случаи, когда из-за пропажи документов отсутствуют промежуточные звенья в цепи предков например, от зафиксированного родоначальника через одно-два (а то и больше) незафиксированных поколения к потомкам. Если наша гипотеза верна, то в числе предков необходимо учесть и 19 колено с именем «Котег» («Котэг», «Катег»), от которого собственно и образовалась фамилия (приблизительная хронология - конец XV - начало XVI вв.). Конечно, данные реконструкции могут оказаться всего лишь реконструкциями, а имя (или прозвище) «Котег» может принадлежать уже Ивану Котегову, и в таком случае глубже 17 колена продвинуться никак не удастся, но, с другой стороны, дефицит информации не отрицает и тот факт, что имя (или прозвище) «Котег» мог носить и дед Ивана Иванова сына Котегова, а следовательно, и первоначально высказанная гипотеза о предке в 19 колене также может иметь право на существование.

С позиции образования фамилии «Котегов» перед нами выстраивается следующая цепочка: Иван Котегов доводится сыном человеку по фамилии «Котегов». Возможно, что Иван Котегов получил фамилию случайным образом, например, будучи подсоседником настоящего Котегова или приёмышем в чужой семье. Но если мы отбросим эту дополнительную гипотетичность, то получим связь «Котег - Котегов - сын Котегов». <..> На примере Ивана Котегова можно углубить родословную линию на 2 колена («Котег» и «Котегов»), однако точно определить количество колен от «Котег» до «Котегов» (ведь отчество (или даже дедичество) 
«Котегов» может передаться от более дальнего предка, а не обязательно непосредственно от отца) и от «Котег - Котегов» до «сын Котегов» проблематично. Может так оказаться, что никаких промежуточных безымянных колен вовсе не существовало, но достоверно (кроме установленного антиязыкового статуса реконструированных предков) об этом нельзя поручиться (см.: [33]).

Проанализируем ещё один пример: Тимошко Дмитриев сын Ярафеев прозвище Камар (Строганова слобода Новое Усолье, 1647) [34, с. 88; 35, л. 335]. Впоследствии от прозвища «Камар» образуется фамилия «Комаров» («Камаров), а пока посмотрим, какова поколенческая преемственность. Отца Тимошки звали Дмитрий. Деда Тимошки звали Ярафеем (Иерофеем, Ерофеем), хотя, вполне возможно, что и не деда, а прадеда. Форма «Ярафеев» может быть как отчеством, так и дедичеством для Дмитрия (прадедичеством (?) для Тимошки). Маловероятно, но допустимо, что форма «Ярафеев» для Дмитрия могла быть и прадедичеством (а теперь посчитайте, сколько потенциально поименованных предков может предполагать данная языковая форма). В том же документе в Орле-городке мы находим ещё и Андрюшку Дмитриева сына Комара, вероятно, родного брата Тимошки [34, с. 90; 35, л. 338об.].

Антиязыковой статус имён предков указывает на то, что именной состав данных языковых единиц доступен для документального подтверждения или реконструкции, правда, при наличии классических источниковедческих (например, архивные документы) и лингвистических доказательств (например, указания на степени родства). Однако именно антиязыковой статус таких имён собственных помогает не ограничиваться только документально подтверждёнными фактами, а рассчитывать на максимально объективное (хотя и предположительное) восстановление родословной, применяя метод антропонимической экстраполяции.

Рассмотрим такой необычный пример, имеющийся в генеалогических исследованиях, как наличие прямого предка без имени, но с документально установленными фамилией (Смирнов), отчеством (Петров сын) и фамилией и отчеством (Петров сын Смирнов). Допустим, известно, что ваши предки жили в некотором населённом месте, жители которого зафиксированы в сказке первой ревизии (1719-1729), а другие ревизии вплоть до восьмой ревизии (1834) не сохранились. Если также не сохранились никакие другие первоисточники (метрические книги, исповедные росписи и т.п.), то вы столкнётесь с большими лакунами в несколько поколений. Тем не менее, вполне возможно оперировать неполными именами собственными предков, которые логически (поколенчески) восстановимы.
Например, в первой ревизии имеется Иван Петров сын Смирнов (возраст: 15 лет, холост), который может доводиться вам прямым предком спустя несколько поколений через указанного в восьмой ревизии Максима Афанасьева сына Смирнова (возраст: 30 лет, женат). Отталкиваясь от Максима Афанасьева сына Смирнова, который родился в около 1804 г., вы можете установить приблизительное время рождения его отца - Афанасия, который мог родиться в начале 1780-х гг. (но до 1789 г., так как иначе бы в 1804 г. ему было всего 15 лет от роду, а церковные браки могли заключаться только при достижении 16-летия). Ваш потенциальный прямой потомок от Ивана Петрова сына Смирнова, чьё имя собственное будет состоять из отчества и фамилии («Иванов сын Смирнов»), мог родиться в 17201730-е гг. Следовательно, от Афанасия его может отделять всего одно поколение: человек с частичным именем собственным «Иванов сын Смирнов» родил сына в 1750-1760-е гг. (имя собственное в одну фамилию «Смирнов»), который в свою очередь родил сына Афанасия сына Смирнова в 1780-е гг. (но до 1789 г.). Благодаря такой аналогии можно реконструировать имена собственные для своих прямых предков, и, разумеется, они будут носить антиязыковой (в данном случае документально не удостоверенный) характер (сравните с генеалогическим «законом трёх поколений», согласно которому на одно столетие, как правило, приходится деятельность трёх мужских и четырёх женских поколений). Следует заметить, что по такой аналогии можно поименовать многих наших предков, привязав этот номинативный алгоритм ко времени образования фамилий в той или иной местности - например, к XVII в. для Пермского уезда, в котором массовое образование фамилий пришлось на середину столетия. Ср.: Е.Н. Полякова: «Результатом самой ранней переписи в Прикамье были писцовые книги Перми Великой (то есть северной части Пермского края) Ивана Яхонтова 1579 г. В это время переписчики обходились преимущественно двухкомпонентными сложными антропонимами двух видов.

К первому виду относились антропонимы, состоящие из календарного имени человека и его именования по отцу (из календарного имени отца), например: в деревне Цыдве на реке Цыдве записаны крестьяне Мартынко Гаврилов (от имени отца Гаврило), Ивашко Савин, Данилко Никифоров, Михалка да Илейка Афанасьевы [Я: 25]. Именования Гаврилов, Савин, Данилов, Афанасьев в книге 1579 г. являлись практически отчествами. Исследователи их называют также полуотчествами, так как в них еще не было обычного для отчества суффикса -вич (Гаврилович, Афанасьевич), первоначально принятого только для бояр или лиц, которым в 


\section{Филология: научные исследования 1(21) • 2016}

XVI в. специальным царским указом давалось право именоваться “с вичем"» [36, с. 9].

Так, например, в нашей родословной имеется род Карловых, который впервые встречается в архивных документах с середины XVII в. в селе Калабино Елецкого уезда (будущая Воронежская губерния). Однако вследствие того, что Государственный архив Воронежской области сильно пострадал во время Великой Отечественной войны, документов по данному региону сохранилось немного. Если взять такой важный первоисточник, как ревизские сказки, то по селу Калабино они сохранились очень плохо: в РГАДА первая (1722-1727), по убывшим после первой (1748), вероятно, вторая (1744-1746) и третья (1762) ревизии, а в Государственном архиве Воронежской области (ГАВО) - пятая (1795) ревизия, тогда как за XIX в. - практически ничего. C метрическими книгами по Богородицкой церкви села Калабино ситуация ещё хуже, поэтому проследить нашу линию Карловых со 2-й половины XIX в. до середины XVII в. не представляется возможным за исключением кропотливого отслеживания всех ветвей рода Карловых, одна из которых потенциально должна являться нашей прямой линией. Имена собственные в этих реконструированных ветвях будут представлять собой антислова - генеалогизмы.

Антиязыковую методологию можно использовать и для легендарных предков (пращуров), носящих ваши фамилии, но промежуточные потомки (колена) которых документально непрослеживаемы по различным причинам. В этом случае не обязательна географическая привязка к конкретному месту жительства ваших документально установленных предков, так как за столетия они могли мигрировать несколько раз, а фамилия практически без изменений передавалась по наследству (ср.: В.Б. Кобрин: «...В.В. Палагина обратила внимание на различия и в именнике, и в структуре наименований в зависимости от местности, что открывает интересные перспективы для генеалогических и общеисторических исследований» [26, с. 198]; см. также: [37]). Конечно, этот пример может быть характерен для редких фамилий, однако благодаря генетическим исследованиям стало доступным определять приблизительное время жизни общего предка (TMRCA - Time to the Most Recent Common Ancestor) и соотносить его с документальным пращуром (снипование как именование в ДНК-генеалогии).

Иллюстрацию антиязыковой номинации можно продолжить и для такого случая, когда неизвестно имя вашего прямого предка-женщины, но по косвенным сведениям (через зафиксированное родство) можно восстановить родственную связь. Имеется в виду отсутствие имени жены, но известны её отчество и фамилия (или только отчество, ведь жена указана по фамилии мужа; хотя при повторном супружестве могут быть отмечены девичьи фамилии второ- и третьебрачных), определённые через восприемника для ребёнка этой пары, в качестве которого, например, выступает свояк отца младенца. Свояк - это муж сестры жены. Зная точное имя (ФИО) жены восприемника, можно по аналогии установить отчество и девичью фамилию для искомой жены. Имя собственное жены будет неполным - только отчество и фамилия. Также возможны любые другие родственные варианты, помогающие реконструировать подлинные, хотя и частичные, имена собственные. У генеалогов считается большой удачей найти в метрических записях указания на родственные отношения. От фактологической скрупулёзности писаря зависело, будет ли указана степень родства восприемника/восприемников новорождённому/родившим родителям или вам придётся отыскивать иные прямые и косвенные доказательства такого родства. Нередки случаи, когда не удаётся точно установить девичью фамилию жены даже при наличии ревизских записей. Например, в нашем случае нам известны имя и отчество жены Тимофея Карпова Овчинникова (предок в 11-м колене), но её девичья фамилия в двух разных документах записана то как Мелехина (3-я ревизия 1763 г.) [22, л. 53], то как Мехоношина (4-я ревизия 1782 г.) [38, л. 303]. Выявить в архивных источниках её отца - Илью - пока не удалось, причём обе эти фамилии встречаются независимо друг от друга. Поэтому онтологический статус данной девичьей фамилии в антиязыковой парадигме будет также антисловным (неполный генетизм), несмотря на документальное наличие обоих вариантов. Другой пример также касается установления девичьей фамилии, причём имеется метрическая запись о браке, где фамилия указана, но, вероятно, записана ошибочно. Приведём полностью эти данные: «24 октября 1791 г. села Старого Посаду отрок Павел Васильев сын Василков понял Степановского приходу деревни Колпашниковы у крестьянина Якова Михайлова дочь ево девку Феодору» [39, л. 45об.]. Дело в том, что в деревне Колпашниковой по данным 3-й ревизской сказки 1762 г. не проживало крестьян по фамилии Михайловы. Скорее всего, речь может идти о крестьянине Якове Михайлове сыне Яковлеве, которому на момент 3-й ревизии было 29 лет [40, л. 873]. К сожалению, 4-й ревизии 1782 г. по Колпашниковой не сохранилось, однако по переписи 1778 г. в деревне значится 45-летний крестьянин Яков Яковлев (без отчества), которого, наверное, по ошибке записали в метрической книге как Якова Михайлова, употребив отчество «Михайлов» вместо опущенной фамилии «Яковлев» [41, л. 815об.]. 
Отдельно следует отметить случаи с происхождением фамилий от прозвищ (прозваний), которые давались людям по их чертам характера, географическому происхождению, роду занятий. Таких критериев образования фамилий выделяют больше десятка, хотя нам интересен сам факт такого именования (фамилеобразования) для создания антисловных по своему статусу имён собственных. Возьмём такую фамилию, как «Овчинников». Она образована от прозвища «Овчинник» (по роду занятия: изготовитель овчин). Понятно, что фамилия в форме «Овчинников» могла передаться как самому носителю прозвища (в более поздних документальных фиксациях), так и потомку - сыну (и не только через сыново поколение, а, например, только внуку или даже правнуку; смотрите пример ниже). Видимо, алгоритм передачи фамилии во многом зависел от критерия происхождения самой фамилии. В этом смысле относительно прозрачно образование фамилий от имён людей, от которых можно почти поколенно проследить закрепление фамилии. Правда, как показывают первоисточники, происхождение прозвищ и закрепление их в фамилию происходило не обязательно по схеме: от имени собственного, включающего имя и фамилию, к имени собственному предка, который мог быть носителем прозвища, то есть: реконструированный из отчества потомка Семён Овчинников - сын человека, чьё прозвище было «Овчинник». Реконструированный Семён Овчинников мог сам носить прозвище «Овчинник», но в результате реконструкции возникает соблазн в углублении родословной линии ещё на одно поколение: на человека с прозвищем «Овчинник», чьим сыном был реконструированный Семён Овчинников. Нередки случаи, когда прозвище носил человек, у которого имелось полное имя собственное - имя, отчество и фамилия, а его потомки носили фамилию, образованную от прижизненного прозвища такого предка, то есть обладали двойной фамилией.

Собственно говоря, позаимствуем из нашей родословной пример с фамилией «Овчинников». Наш род Овчинниковых происходит из Кайгородского уезда, где впервые зафиксирован в переписной книге 1678 г. в деревне, что была Баженка Горшкова, Волосницкой волости Кайгородского уезда, куда семья Кондратия Семёнова сына Овчинникова переселилась в 184 г. (1675/1676) из Лоенской волости [42, л. 136]. По сказке 1703 г., когда Овчинниковы уже проживали в деревне Сухой речке [43, л. 205-205об.] шесть лет, т.е. с 1697 г., местом их рождения указана деревня Турнаевская Лоенского прихода Кайгородского уезда. В переписной книге Кайгородского уезда 1678 г. мы находим деревню Трубиновскую - бывший починок Турнаевской на ключе [42, л. 86-86об.]. Однако Овчинниковы там не зафиксированы, видимо, потому, что они переселились в соседнюю волость - Волосница, а также в соседний Кунгурский уезд, где по переписной книге 1679 г. в Сухой речке уже проживала семья Андрейки Иванова сына Овчинникова [44, л. 40об.]. По сказке 1703 г. указано, что данная семья Овчинниковых также родом из деревни Турнаевой Кайгородского уезда [43, л. 173-173об.]. Таким образом, можно сделать предположение о том, что обе семьи Овчинниковых являются близкими родственниками, в разное время перебравшиеся в Сухую речку (возможно, двоюродными братьями). Благодаря антиязыковому методу вероятно реконструировать родоначальника нашего рода Овчинниковых человека с прозвищем «Овчинник», который может доводиться дедом документально зафиксированному Кондрашке Семёнову сыну Овчинникову.

Помимо собственно антиязыковых примеров генеалогизмов можно отметить такие их разновидности, которые обозначают вариативные имена собственные: имена, отчества и фамилии (по отдельности или все вместе). В силу разночтения первоисточников могут быть восстановлены предки с разными именами собственными, среди которых трудно отдать предпочтение тому или другому. Описки и ошибки в документообороте - ощутимый фактор в образовании имён собственных.

Одной из особенностью имён собственных, следовательно, и генеалогизмов, является то, что данные языковые единицы встречаются в документах малократно, а при утрате последних - вообще потеряны для языка. Но только не для антиязыка. Имена собственные, зафиксированные в документах единожды, представляют собой разновидность гапаксов (единожды документально употреблённые имена собственные), а при уничтожении документальных носителей - разновидностью гапаксологизмов. Реконструированные формы имён собственных для родословного поиска в качестве генеалогизмов могу быть также отнесены к классу праформологизмов (этимонологизмов) - реконструированных праформ слов (этимонов), в частности, имён собственных.

В качестве генеалогизмов могут выступать ошибочно установленные имена собственные предков (или других родственников), что объясняется нехваткой необходимых (прямых или косвенных) документов, а также неправильной интерпретацией родственных связей (см.: [45], [46]). Некорректное родство может быть обусловлено описками и ошибками в первоисточниках, на основании которых выводятся те или иные родственные связи. И тогда такие имена собственные получают негативный статус генеалогизмов как антислов. Ни 
один генеалог не застрахован от неверно установленных фактов, тем более что сохранность первоисточников бывает очень плохой. Если, например, архивное дело не подлежит реставрации, а в нём могут содержаться важные родословные сведения, то таковые имена собственные, не подлежащие физическому восстановлению, вынужденно представляют собой антислова. Такие генеалогизмы как косвенные антислова находятся в подвешенном состоянии - оставаясь в качестве и обычных имён собственных (соответствующие языковые единицы), и необычных имён собственных (соответствующие антиязыковые единицы). А если допустить, что такие не востребованные ни языком, ни антиязыком генеалогизмы гипотетически могут быть неправильно распределены среди родословных линий (например, неправильно идентифицированы с реальным предком, когда имя собственное документально вроде бы указано, пускай и невозможно им воспользоваться, однако данный человек может не являться генетическим предком), то в таком случае следовало бы говорить о двойной негативности («псевдости») генеалогизмов как антислов (квазигенеалогизмы).

Также следует упомянуть и о таких случаях, когда из-за плохой сохранности документа (например, выцветшие чернила) совсем или частично не прочитывается то или иное имя собственное. Бывает, что лист повреждён именно в том месте, где записано искомое имя, дошедшее до нас в виде фрагмента. Все подобные примеры важно учитывать при реконструкции имён собственных в статусе генеалогизмов как антислов.

Любое генеалогическое изыскание напоминает детективное расследование, в рамках которого используются различного рода улики. Конечно, самыми вескими уликами являются имена собственные наших предков, в открытии которых мы нередко пользуемся интуитивными и вспомогательными средствами удостоверения. В результате использования таких рассудочных приемов устанавливаются имена собственные, чья достоверность может оказаться весьма сомнительной (например, при установлении девичьей фамилии по имени, отчеству и дате рождения жены, когда фронтальному изучению подвергается целый церковный приход (а то и волость, и уезд, и губерния) для валидно-исчерпывающего анализа). Впрочем, степень достоверности тех или иных родословных данных остаётся на усмотрении у каждого родоведа, ведь после появления такой новой науки, как ДНК-генеалогия (генетическая генеалогия), документальная гарантия достоверности данных не лишена определенной доли критики. Антисловными именами собственными могут оказаться и вполне «документабельные» сведения, не вызывающие никаких сомнений, но после проведения ДНК-анализа по установлению той или иной степени родства подвергающие критике подлинность ранее найденных фактов.

Антиязыковая методология, находясь на службе у генеалогии, конкретизирует известный в отечественной философии долг патрофикации, сформулированный русским мыслителем Н.Ф. Фёдоровым в его сборнике «Философия общего дела». Идея «патрофикации» (воскрешения отцов) означала для него буквальное воссоздание всех прежде живших поколений предков, то есть достижение всеобщего бессмертия. Воскрешение как «общее дело» есть нравственный долг живущих (сынов) перед умершими (отцами).

В свете всего сказанного подытожим следующее: антиязыковая методология безусловно расширяет возможности генеалогических исследований, предоставляя гипотетико-лингвистические гарантии для максимально полного (см.: [47]) восстановления имён собственных наших далёких предков.

\section{Список литературы:}

1. Харченко В.К., Черникова Е.М. Лингвогенеалогия: Имя собственное в жанре семейных родословных. М., 2010.

2. Бахтин М.М. Дополнения и изменения к «Рабле» // Вопросы философии. 1992. № 1. С. 134-164.

3. Нилогов А.С. Философия антиязыка. СПб., 2013.

4. Нилогов А.С. Онтологический статус слова/антислова // Филология: научные исследования. 2015. № 3. С. $241-252$. DOI: 10.7256/2305-6177.2015.3.16615.

5. Метрическая книга Косинской Николаевской церкви для записи родившихся, браком сочетавшихся и умерших за 1843 год // Государственный архив Пермского края. Ф. 719. Оп. 10. Д. 1173.

6. Метрические книги Чердынского уезда за 1760-1779 годы // Государственный архив Пермского края. Ф. 37.0 О. 3. Д. 303. [Электронный ресурc] URL: http://www.pokolenia.permkrai.ru/Perm/\%D0\%A4.37.\%D0\%9E\%D0\%BF.3.\%D0 \%94.303/ (дата обращения: 01.01.2016).

7. Метрические книги Косинской Николаевской церкви для записи родившихся, браком сочетавшихся и умерших за 1800-1829 годы // Поколения Пермского края. [Электронный ресурc] URL: https://pokolenia.permkrai.ru/ geography/view/56 (дата обращения: 01.01.2016).

8. Метрическая книга Косинской Николаевской церкви для записи родившихся, браком сочетавшихся и умерших за 1767 год // Государственный архив Пермского края. Ф. 37. Оп. 3. Д. 303. [Электронный pecypc] URL: http:// www.pokolenia.permkrai.ru/Perm/\%D0\%A4.37.\%D0\%9E\%D0\%BF.3.\%D0\%94.303/00000381.jpg (дата обращения: 01.01.2016). 


\section{Языкознание}

9. Ревизская сказка Чердынского уезда 1834 года // Государственный архив Пермского края. Ф. 111. Оп. 1. Д. 2358.

10. Ревизская сказка Чердынского уезда 1762 года // Российский государственный архив древних актов. Ф. 350.0 П. 2. Д. 4055.

11. Нилогов А.С. Откуда есть пошли Нилоговы // Генеалогический вестник. 2012. № 44. С. 27-55.

12. Переписная книга Чердыни (Перми Великой) 10.4.7186 (10(20).4.1678) года переписи князя Фёдора Фёдоровича Бельского и подьячего Якова Меншикова // Российский государственный архив древних актов. Ф. 1209. Оп. 1. Д. 352.

13. Писцовая книга Михаила Фёдоровича Кайсарова, дьяка Марка Мартемьянова, да подьячих Исака Леонтьева, да Афанасия Бреева Перми Великой 7131 и 7132 (1623 и 1624) гг. Список с переписных книг // Российская государственная библиотека. Отдел рукописей. Ф. 256. Д. 308.

14. Копия «Книги сошного письма города Камского посада письма и меры писца Ивана Яхонтова и подьячего Третьяка Карпова 1578/1579 гг.» (список со списка, включённый в сборник 2-й пол. XVIII в.) // Архив Санкт-Петербургского Института истории РАН. Ф. 115. ОП. 1. Д. 442.

15. Переписная книга Перми Великой (Чердыни) 7.4 .7155 (7(17).4.1647) года переписи воеводы Прокофия Кузьмича Елизарова. Подлинник // Российский государственный архив древних актов. Ф. 1209. Оп. 1. Д. 351.

16. Писцовая книга Ивана Игнатьевича Яхонтова да подьячего Третьяка Карпова Перми Великой 7087 (1578/1579) г. Список с переписных книг // Российская государственная библиотека. Отдел рукописей. Ф. 256. Д. 308.

17. Копия «Книги сошного письма города Камского посада письма и меры писца Ивана Яхонтова и подьячего Третьяка Карпова 1578/1579 гг.» (список со списка, включённый в сборник 2-й пол. XVIII в.) // Архив Санкт-Петербургского Института истории РАН. Ф. 115. Оп. 1. Д. 442.

18. Книги сошного письма Пермские-Чердынские и Чердынского уезда письма и меры писца Ивана Игнатьевича Яхонтова да подьячего Третьяка Карпова восемьдесят седьмого года (1579 года) с некоторыми пояснениями В.Н. Шишонко. Пермь, 1879.

19. Межевая книга Чердынского и Усольского уезда Сарыча Шестакова 117 года (1608/1609 годов) // Архив СанктПетербургского Института истории РАН. Ф. 115. Оп. 1. Д. 920.

20. Сабитов Ж.М. Этногенез казахов с точки зрения популяционной генетики // The Russian Journal of Genetic Genealogy (Русская версия). 2013. Т. 5. № 1. С. 29-47. [Электронный ресурc] URL: http://rjgg.molgen.org/index.php/RJGGRE/ article/view/129/147 (дата обращения: 01.01.2016).

21. Метрическая книга Свято-Троицкой церкви с. Старый посад Кунгурского уезда (Кунгурской (Пермской) провинции) Казанской губернии для записи родившихся, браком сочетавшихся и умерших за 1756 год // Государственный архив Вятской области. Ф. 237. Оп. 74. Д. 1690.

22. Сказки о государственных крестьянах и крестьянах, приписанных к Курашимскому медеплавильному заводу И. Осокина Кунгурского уезда за 1762-1763 годы // Российский государственный архив древних актов. Ф. 350. Оп. 2. Д. 1639.

23. Сказки посадских людей, государственных черносошных, епископских, ясачных (татары, мари) крестьян, бобылей г. Кунгура, Степановского, Торговишского, Ильинского, Вознесенского и Покровского острожков Карьевской, Сылвенской, Верхиренской, Шалвинской четвертей Кунгурского уезда за 1719 год // Российский государственный архив древних актов. Ф. 350. Оп. 2. Д. 1625.

24. Волков В.Г. Все ли Рюриковичи происходят от одного предка? [Электронный pecypc] URL: http://trog.narod.ru/ articles/rurikids/Rurikids.htm, http://trog.narod.ru/articles/rurikids/Rurikids.pdf (дата обращения: 01.01.2016).

25. Клёсов A.A. Происхождение Рюриковичей: ДНК-генеалогия доказывает. [Электронный pecypc] URL: http:// pereformat.ru/2013/02/ryurikovichi/ (дата обращения: 01.01.2016).

26. Кобрин В.Б. Опричнина. Генеалогия. Антропонимика. М., 2008.

27. (1614/1615) г. - Дозорная книга посадов и тяглых деревень вятских городов и уездов письма и дозора воевод кн. Фёдора Андреевича Звенигородского, Василия Терентьевича Жемчужникова и дьяка Михаила Ордынцева (Ординцова), Черновик подлинника за скрепами кн. Ф.А. Звенигородского и дьяка М. Ордынцева // Российский государственный архив древних актов. Ф. 1209. Оп. 1. Д. 1029.

28. (1614/1615) г. - Дозорная книга монастырских вотчин и оброчных лавок, пожень, кузниц, рыбных ловель на посаде и в уездах вятских городов письма и дозора воевод кн. Фёдора Андреевича Звенигородского, Василия Терентьевича Жемчужникова и дьяка Михаила Ордынцева (Ординцова), Подлинник за скрепой кн. Ф.А. Звенигородского // Российский государственный архив древних актов. Ф. 1209. Оп. 1. Д. 1030.

29. Словарь пермских фамилий / Сост. Е.Н. Полякова. Пермь, 2005.

30. Кривощёкова-Гантман А.С. Фамилии от имён на-ог,-ег // Ономастика Поволжья. Вып. 4. Саранск, 1976. С. $91-94$.

31. Кривощёкова-Гантман А.С. Русские фамилии коми-пермяцкого происхождения // Языки и ономастика Прикамья. Пермь, 1973. С. 76-86.

32. Бушмакин С.К. Дохристианские личные имена удмуртов // Личные имена в прошлом, настоящем, будущем. М., 1970. С. 263-267.

33. Нилогов А.С. Откуда есть пошли Котеговы // Генеалогический вестник. 2014. № 49. С. 28-36.

34. Переписная книга воеводы Прокопья Козмича Елизарова 7155 (1647) г. по вотчинам Строгановых // Труды Пермской учёной архивной комиссии. Пермь, 1893. Вып. 2. С. 87-146.

35. (1647), 27 марта (6 апреля). - Переписная книга Соликамского уезда воеводы Прокофия Кузьмича Елизарова. Подлинник // Российский государственный архив древних актов. Ф. 1209. Оп. 1. Д. 474.

36. Полякова Е.Н. Формирование пермских отымённых фамилий в XVII-XVIII веках // Вестник Пермского университета. 2010. Вып. 3(9). С. 7-17.

37. Палагина В.В. К вопросу о локальности русских антропонимов конца XV-XVII вв. // Вопросы русского языка и говоров. Труды Томского гос. ун-та им. В.В. Куйбышева. 1968. Т. 197. С. 83-92. 


\section{Филология: научные исследования 1(21) • 2016}

38. О приписных и государственных крестьянах Кунгурской округи Пермского наместничества 1782 года // Государственный архив Пермского края. Ф. 111. Оп. 3. Д. 374.

39. Метрическая книга Свято-Троицкой церкви с. Старый посад Осинского уезда Пермской губернии для записи родившихся, браком сочетавшихся и умерших за 1791 год // Государственный архив Пермского края. Ф. 109. Оп. 1. Д. 148.

40. Сказки о государственных крестьянах и крестьянах, приписанных к бывшим казённым Юговским медеплавильным заводам и медеплавильным заводам М.И. Воронцова; Ильинского, Медянского, Вознесенского, Торговижского, Покровского, Степановского острожков Кунгурского уезда 1762 года // Российский государственный архив древних актов. Ф. 350. Оп. 2. Д. 1637.

41. Перепись Кунгурского уезда 1778 года // Государственный архив Свердловской области. Ф. 116. Оп. 1. Д. 133.

42. (1678) г., август. - Переписная книга города Кайгородка и Кайгородского уезда переписи Никиты Даниловича Глебова и подьячего Тимофея Антропова // Российский государственный архив древних актов. Ф. 1209. Оп. 1. Д. 184.

43. (1703) г. - Дозорная книга Кунгурского уезда // Российский государственный архив древних актов. Ф. 214. Оп. 1. Д. 1254.

44. (1679) г., янв. 20(30). - Переписная книга Кунгурского уезда переписи Дмитрия Романовича Жукова и подьячего Петра Ахматова // Российский государственный архив древних актов. Ф. 1209. Оп. 1. Д. 226.

45. Шумков А.А. Псевдогенеалогические проблемы идентификации однофамильцев (доклад) // Третьи Петербургские генеалогические чтения «Однофамильные роды». 11 ноября 1999 г., Санкт-Петербург.

46. Елькин М.Ю. Проблемы, возникающие при составлении родословий однофамильцев // Материалы Третьей Уральской родоведческой научно-практической конференции (14-15 ноября 2003 г., Екатеринбург). Екатеринбург, 2007. С. 19-22.

47. Елькин М.Ю. Генеалогия: частная, комплексная, тотальная // Грибушинские чтения - 2013. Летопись наследия. Тезисы докладов и сообщений IX Международного социально-культурного форума (г. Кунгур, 22-27 апреля 2013 г.). Пермь, 2013. С. 25-30.

\section{References (transliterated):}

1. Kharchenko V.K., Chernikova E.M. Lingvogenealogiya: Imya sobstvennoe v zhanre semeinykh rodoslovnykh. M., 2010.

2. Bakhtin M.M. Dopolneniya i izmeneniya k «Rable» // Voprosy filosofii. 1992. № 1. S. 134-164.

3. Nilogov A.S. Filosofiya antiyazyka. SPb., 2013.

4. Nilogov A.S. Ontologicheskii status slova/antislova // Filologiya: nauchnye issledovaniya. 2015. № 3. S. $241-252$. DOI: 10.7256/2305-6177.2015.3.16615.

5. Metricheskaya kniga Kosinskoi Nikolaevskoi tserkvi dlya zapisi rodivshikhsya, brakom sochetavshikhsya i umershikh za 1843 god // Gosudarstvennyi arkhiv Permskogo kraya. F. 719. Op. 10. D. 1173.

6. Metricheskie knigi Cherdynskogo uezda za 1760-1779 gody // Gosudarstvennyi arkhiv Permskogo kraya. F. 37.0 p. 3. D. 303. [Elektronnyi resurs] URL: http://www.pokolenia.permkrai.ru/Perm/\%D0\%A4.37.\%D0\%9E\%D0\%BF.3.\%D0\%94. 303/ (data obrashcheniya: 01.01.2016).

7. Metricheskie knigi Kosinskoi Nikolaevskoi tserkvi dlya zapisi rodivshikhsya, brakom sochetavshikhsya i umershikh za 1800-1829 gody // Pokoleniya Permskogo kraya. [Elektronnyi resurs] URL: https://pokolenia.permkrai.ru/geography/ view/56 (data obrashcheniya: 01.01.2016).

8. Metricheskaya kniga Kosinskoi Nikolaevskoi tserkvi dlya zapisi rodivshikhsya, brakom sochetavshikhsya i umershikh za 1767 god // Gosudarstvennyi arkhiv Permskogo kraya. F. 37. Op. 3. D. 303. [Elektronnyi resurs] URL: http://www.pokolenia. permkrai.ru/Perm/\%D0\%A4.37.\%D0\%9E\%D0\%BF.3.\%D0\%94.303/00000381.jpg (data obrashcheniya: 01.01.2016).

9. Revizskaya skazka Cherdynskogo uezda 1834 goda // Gosudarstvennyi arkhiv Permskogo kraya. F. 111. Op. 1. D. 2358.

10. Revizskaya skazka Cherdynskogo uezda 1762 goda // Rossiiskii gosudarstvennyi arkhiv drevnikh aktov. F. 350. Op. 2. D. 4055.

11. Nilogov A.S. Otkuda est' poshli Nilogovy // Genealogicheskii vestnik. 2012. № 44. S. 27-55.

12. Perepisnaya kniga Cherdyni (Permi Velikoi) 10.4.7186 (10(20).4.1678) goda perepisi knyazya Fedora Fedorovicha Bel'skogo i pod'yachego Yakova Menshikova // Rossiiskii gosudarstvennyi arkhiv drevnikh aktov. F. 1209. Op. 1. D. 352.

13. Pistsovaya kniga Mikhaila Fedorovicha Kaisarova, d'yaka Marka Martem'yanova, da pod'yachikh Isaka Leont'eva, da Afanasiya Breeva Permi Velikoi 7131 i 7132 (1623 i 1624) gg. Spisok s perepisnykh knig // Rossiiskaya gosudarstvennaya biblioteka. Otdel rukopisei. F. 256. D. 308.

14. Kopiya «Knigi soshnogo pis'ma goroda Kamskogo posada pis'ma i mery pistsa Ivana Yakhontova i pod'yachego Tret'yaka Karpova 1578/1579 gg.» (spisok so spiska, vklyuchennyi v sbornik 2-i pol. XVIII v.) // Arkhiv Sankt-Peterburgskogo Instituta istorii RAN. F. 115. Op. 1. D. 442.

15. Perepisnaya kniga Permi Velikoi (Cherdyni) 7.4.7155 (7(17).4.1647) goda perepisi voevody Prokofiya Kuz'micha Elizarova. Podlinnik // Rossiiskii gosudarstvennyi arkhiv drevnikh aktov. F. 1209. Op. 1. D. 351.

16. Pistsovaya kniga Ivana Ignat'evicha Yakhontova da pod'yachego Tret'yaka Karpova Permi Velikoi 7087 (1578/1579) g. Spisok s perepisnykh knig // Rossiiskaya gosudarstvennaya biblioteka. Otdel rukopisei. F. 256. D. 308.

17. Kopiya «Knigi soshnogo pis'ma goroda Kamskogo posada pis'ma i mery pistsa Ivana Yakhontova i pod'yachego Tret'yaka Karpova 1578/1579 gg.» (spisok so spiska, vklyuchennyi v sbornik 2-i pol. XVIII v.) // Arkhiv Sankt-Peterburgskogo Instituta istorii RAN. F. 115. Op. 1. D. 442.

18. Knigi soshnogo pis'ma Permskie-Cherdynskie i Cherdynskogo uezda pis'ma i mery pistsa Ivana Ignat'evicha Yakhontova da pod'yachego Tret'yaka Karpova vosem'desyat sed'mogo goda (1579 goda) s nekotorymi poyasneniyami V.N. Shishonko. Perm', 1879.

19. Mezhevaya kniga Cherdynskogo i Usol'skogo uezda Sarycha Shestakova 117 goda (1608/1609 godov) // Arkhiv SanktPeterburgskogo Instituta istorii RAN. F. 115. Op. 1. D. 920.

20. Sabitov Zh.M. Etnogenez kazakhov s tochki zreniya populyatsionnoi genetiki // The Russian Journal of Genetic Genealogy (Russkaya versiya). 2013. T. 5. № 1. S. 29-47. [Elektronnyi resurs] URL: http://rjgg.molgen.org/index.php/RJGGRE/article/ view/129/147 (data obrashcheniya: 01.01.2016). 
21. Metricheskaya kniga Svyato-Troitskoi tserkvi s. Staryi posad Kungurskogo uezda (Kungurskoi (Permskoi) provintsii) Kazanskoi gubernii dlya zapisi rodivshikhsya, brakom sochetavshikhsya i umershikh za 1756 god // Gosudarstvennyi arkhiv Vyatskoi oblasti. F. 237. Op. 74. D. 1690.

22. Skazki o gosudarstvennykh krest'yanakh i krest'yanakh, pripisannykh k Kurashimskomu medeplavil'nomu zavodu I. Osokina Kungurskogo uezda za 1762-1763 gody // Rossiiskii gosudarstvennyi arkhiv drevnikh aktov. F. 350. Op. 2. D. 1639.

23. Skazki posadskikh lyudei, gosudarstvennykh chernososhnykh, episkopskikh, yasachnykh (tatary, mari) krest'yan, bobylei g. Kungura, Stepanovskogo, Torgovishskogo, Il'inskogo, Voznesenskogo i Pokrovskogo ostrozhkov Kar'evskoi, Sylvenskoi, Verkhirenskoi, Shalvinskoi chetvertei Kungurskogo uezda za 1719 god // Rossiiskii gosudarstvennyi arkhiv drevnikh aktov. F. 350. Op. 2. D. 1625.

24. Volkov V.G. Vse li Ryurikovichi proiskhodyat ot odnogo predka? [Elektronnyi resurs] URL: http://trog.narod.ru/articles/ rurikids/Rurikids.htm, http://trog.narod.ru/articles/rurikids/Rurikids.pdf (data obrashcheniya: 01.01.2016).

25. Klesov A.A. Proiskhozhdenie Ryurikovichei: DNK-genealogiya dokazyvaet. [Elektronnyi resurs] URL: http://pereformat. ru/2013/02/ryurikovichi/ (data obrashcheniya: 01.01.2016).

26. Kobrin V.B. Oprichnina. Genealogiya. Antroponimika. M., 2008.

27. (1614/1615) g. - Dozornaya kniga posadov i tyaglykh dereven' vyatskikh gorodov i uezdov pis'ma i dozora voevod kn. Fedora Andreevicha Zvenigorodskogo, Vasiliya Terent'evicha Zhemchuzhnikova i d'yaka Mikhaila Ordyntseva (Ordintsova), Chernovik podlinnika za skrepami kn. F.A. Zvenigorodskogo i d'yaka M. Ordyntseva // Rossiiskii gosudarstvennyi arkhiv drevnikh aktov. F. 1209. Op. 1. D. 1029.

28. (1614/1615) g. - Dozornaya kniga monastyrskikh votchin i obrochnykh lavok, pozhen', kuznits, rybnykh lovel' na posade i v uezdakh vyatskikh gorodov pis'ma i dozora voevod kn. Fedora Andreevicha Zvenigorodskogo, Vasiliya Terent'evicha Zhemchuzhnikova i d'yaka Mikhaila Ordyntseva (Ordintsova), Podlinnik za skrepoi kn. F.A. Zvenigorodskogo // Rossiiskii gosudarstvennyi arkhiv drevnikh aktov. F. 1209. Op. 1. D. 1030.

29. Slovar' permskikh familii / Sost. E.N. Polyakova. Perm', 2005.

30. Krivoshchekova-Gantman A.S. Familii ot imen na-og,-eg // Onomastika Povolzh'ya. Vyp. 4. Saransk, 1976. S. 91-94.

31. Krivoshchekova-Gantman A.S. Russkie familii komi-permyatskogo proiskhozhdeniya // Yazyki i onomastika Prikam'ya. Perm', 1973. S. 76-86.

32. Bushmakin S.K. Dokhristianskie lichnye imena udmurtov // Lichnye imena v proshlom, nastoyashchem, budushchem. M., 1970. S. 263-267.

33. Nilogov A.S. Otkuda est' poshli Kotegovy // Genealogicheskii vestnik. 2014. № 49. S. 28-36.

34. Perepisnaya kniga voevody Prokop'ya Kozmicha Elizarova 7155 (1647) g. po votchinam Stroganovykh // Trudy Permskoi uchenoi arkhivnoi komissii. Perm', 1893. Vyp. 2. S. 87-146.

35. (1647), 27 marta (6 aprelya). - Perepisnaya kniga Solikamskogo uezda voevody Prokofiya Kuz'micha Elizarova. Podlinnik // Rossiiskii gosudarstvennyi arkhiv drevnikh aktov. F. 1209. Op. 1. D. 474.

36. Polyakova E.N. Formirovanie permskikh otymennykh familii v XVII-XVIII vekakh // Vestnik Permskogo universiteta. 2010. Vyp. 3(9). S. 7-17.

37. Palagina V.V. K voprosu o lokal'nosti russkikh antroponimov kontsa XV-XVII vv. // Voprosy russkogo yazyka i govorov. Trudy Tomskogo gos. un-ta im. V.V. Kuibysheva. 1968. T. 197. S. 83-92.

38. O pripisnykh i gosudarstvennykh krest'yanakh Kungurskoi okrugi Permskogo namestnichestva 1782 goda // Gosudarstvennyi arkhiv Permskogo kraya. F. 111. Op. 3. D. 374.

39. Metricheskaya kniga Svyato-Troitskoi tserkvi s. Staryi posad Osinskogo uezda Permskoi gubernii dlya zapisi rodivshikhsya, brakom sochetavshikhsya i umershikh za 1791 god // Gosudarstvennyi arkhiv Permskogo kraya. F. 109. Op. 1. D. 148.

40. Skazki o gosudarstvennykh krest'yanakh i krest'yanakh, pripisannykh k byvshim kazennym Yugovskim medeplavil'nym zavodam i medeplavil'nym zavodam M.I. Vorontsova; Il'inskogo, Medyanskogo, Voznesenskogo, Torgovizhskogo, Pokrovskogo, Stepanovskogo ostrozhkov Kungurskogo uezda 1762 goda // Rossiiskii gosudarstvennyi arkhiv drevnikh aktov. F. 350. Op. 2. D. 1637.

41. Perepis' Kungurskogo uezda 1778 goda // Gosudarstvennyi arkhiv Sverdlovskoi oblasti. F. 116. Op. 1. D. 133.

42. (1678) g., avgust. - Perepisnaya kniga goroda Kaigorodka i Kaigorodskogo uezda perepisi Nikity Danilovicha Glebova i pod'yachego Timofeya Antropova // Rossiiskii gosudarstvennyi arkhiv drevnikh aktov. F. 1209. Op. 1. D. 184.

43. (1703) g. - Dozornaya kniga Kungurskogo uezda // Rossiiskii gosudarstvennyi arkhiv drevnikh aktov. F. 214. Op. 1. D. 1254.

44. (1679) g., yanv. 20(30). - Perepisnaya kniga Kungurskogo uezda perepisi Dmitriya Romanovicha Zhukova i pod'yachego Petra Akhmatova // Rossiiskii gosudarstvennyi arkhiv drevnikh aktov. F. 1209. Op. 1. D. 226.

45. Shumkov A.A. Psevdogenealogicheskie problemy identifikatsii odnofamil'tsev (doklad) // Tret'i Peterburgskie genealogicheskie chteniya «Odnofamil'nye rody». 11 noyabrya 1999 g., Sankt-Peterburg.

46. El'kin M.Yu. Problemy, voznikayushchie pri sostavlenii rodoslovii odnofamil'tsev // Materialy Tret'ei Ural'skoi rodovedcheskoi nauchno-prakticheskoi konferentsii (14-15 noyabrya 2003 g., Ekaterinburg). Ekaterinburg, 2007. S. 19-22.

47. El'kin M.Yu. Genealogiya: chastnaya, kompleksnaya, total'naya // Gribushinskie chteniya - 2013. Letopis' naslediya. Tezisy dokladov i soobshchenii IX Mezhdunarodnogo sotsial'no-kul'turnogo foruma (g. Kungur, 22-27 aprelya 2013 g.). Perm', 2013. S. 25-30. 